\title{
ON THE TYPE OF THE GENUS COCCUS, L.
}

BY MRS. C. H. FERNALD, AMHERST, MASS.

The first attempt to separate the species given under Coccus in the Icth edition of the Systema Naturæ of Linneus, was made by Geoffroy, in his Histoire Abregée des Insectes, Vol. I. ( $7_{7} 62$ ), where he placed a part of them under Chermes and left adonidum and phalaridis, with his new species ulmi, under Coccus. Of these species only phalaridis was given under the genus Coccus by Linneus in his roth edition, and is therefore the only species that could be regarded as the type of Coccus so far as Geoffroy is concerned.

In 1802 , Latreille, in Vol. III., p. 267 , of his Hist. Nat. Crust. Ins., established hesperidum as the type of the genus Coccus. I have not been able to find that any of the writers between the appearance of the work of Geoffroy and that of Latreille published anything that would fix the type of Coccus. Leach in I8I5 and Samouelle in I8I9 adopted cacti as the type, but the statement made by Leach that it "inhabits fruit trees" makes it quite certain that he had under consideration neither cacti, L., nor the cochineal insect. Samouelle merely copies Leach. Curtis, in his British Entomology ( 1838 ), gives cacti, L., as the type, but none of these three authors could affect the question, as the type had already been established by Latreille, if not by Genffroy, as shown above.

The phalaridis of Linneus was so obscure an insect that the author himself could not determine whether it was a Coccus, an Aphis or a Chermes. Fonscolombe, in describing his Coccus radicum graminis (Ann. Soc. Ent. Fr. III., 212, 1834), gave the synonymy as follows: Phalaridis (?), Linn., Fab., non C. phalaridis, Enc. Meth. nec Geoffr. Prof. Cockerell has suggested the idea that the phalaridis of Geoffroy was possibly not the same species as the Linnean insect, which is precisely the same idea that Fonscolombe had, as shown by his synonomy. Since it is probably impossible to prove that Geoffroy had any of the Linnean species of the Ioth edition in his restricted genus, the only safe ground will be to adopt the type established by Latreille in 1802 , at least till further light is obtained on the identity of phalaridis, L., which at present is unknown.

If, therefore, we adopt hesperidum as the type of Coccus, the genera Calymnatus and Calypticus of Costa and Lecanium of Burmeister will fall 
as synonyms of Coccus, and a new subfamily name will have to be substituted for Lecaniince and also for the subfamily now called Coccina.

The species cacti, L., as has been shown by Prof. Cockerell, is a Monophlebus and must be known by the name of Monophlebus cacti, L. This insect, so far as can be learned from the writings of those who are known to have had this species before them for study, does not possess colouring matter. When Fabricius and others simply copy the description of Linneus without changing it in any way we must consider it as pertaining to the Linnean species only, but when they add to that description the word "tinctorium," as Fabricius does in some of his later writings, we must conclude that he has confounded the cochineal insect with the Linnean species which has the following synonomy:

Coccus cacti, Linn., Syst. Nat., Ed. X., Vol. I., p. 4.57 ( I $75^{8)}$ ).

Coccus cacti, Linn., Syst. Nat., Ed. XII., Vol. I., p. 742 ( I 766 ).

Coccus cacti, Fab., Syst. Ent., p. 744 (I 775 ).

Coccus cacti, DeGeer, Ins. Vol. 6, P. 447 (г776).

Coccus cacti, Fab., Spec. Ins., Vol. II., p. 395 ( I $\left._{7} S_{I}\right)$ in part.

Coccus cacti, Gmel., Syst. Nat., Ed. XIII., Vol. I., part IV., p. 2220 $(1788-93)$ in part.

Coccus cacti, Fab., Ent. Syst, Vol. IV., p. 227 (I794) in part.

Coccus cacti, Fab., Syst. Rhyng, p. 3 I I ( 1803 ) in part.

Monophlebus cacti, Ckll., Science, n. ser., Vol. XV., p. 7 I 8 (I902).

The cochineal insect, so long confounded with cacti, L., was called by the specific name of cacti through a misapprehension, from the time of Fabricius till Costa, in his Fauna del Regno di Napoli, Emitteri, described the species under the name of Dactylopius coccus, in such a manner that there can be no doubt that he was dealing with the cochineal insect. In 1833 Brandt described it very fully, with excellent illustrations, under the name of Coccus cacti, and, while he supposed he had the Linnean species, his description and illustrations apply only to the cochineal insect. The synonomy of this insect is too extensive to be given here, but will appear in my Catalogue of the Coccidæ soon to be published.

The leading facts in this paper were prepared at my request by my husband, Prof. C. H. Fernald, in reply to questions from Prof. Cockerell, who requested him to publish the results of his investigations on the subject, but as Mr. Fernald does not wish to publish on the Coccidæ, he has turned the matter over to me to prepare for publication. 


\section{$2 \mathrm{BHL}$ Biodiversity Heritage Library}

Fernald, M E. 1902. "On the type of the genus Coccus L." The Canadian entomologist 34, 232-233. https://doi.org/10.4039/Ent34232-9.

View This Item Online: https://www.biodiversitylibrary.org/item/18808

DOI: https://doi.org/10.4039/Ent34232-9

Permalink: $\underline{\text { https://www.biodiversitylibrary.org/partpdf/3626 }}$

\section{Holding Institution}

MBLWHOI Library

\section{Sponsored by}

MBLWHOI Library

\section{Copyright \& Reuse}

Copyright Status: NOT_IN_COPYRIGHT

This document was created from content at the Biodiversity Heritage Library, the world's largest open access digital library for biodiversity literature and archives. Visit BHL at https://www.biodiversitylibrary.org. 